УДК 631.53:633.112.9

(C) 2015

Шевніков М. Я., доктор сільськогосподарських наук, Лотиш І. І., Галич О. П., аспіранти

(науковий керівник - доктор сільськогосподарських наук М. Я. Шевніков)

Полтавська державна аграрна академія

\title{
ОСОБЛИВОСТІ РОЗВИТКУ СОЇ ЗАЛЕЖНО ВІД СТРОКІВ СІВБИ В УМОВАХ ЛІВОБЕРЕЖНОГО ЛІСОСТЕПУ УКРАЇНИ
}

\section{Рецензент - доктор сільськогосподарських наук П. В. Писаренко}

Від строку сівби сої залежить дружність сходів, густота рослин, рівномірність достигання, величина i якість врожаю. Основний критерій вибору строку сівби - стійке прогрівання посівного шару трунту. Мінімальна температура для сходів сої становить близько $+10{ }^{\circ} \mathrm{C}$ за умови подальшого підвищення температури трунту. Прогрівання посівного шару до $+12-14{ }^{\circ} \mathrm{C}$ забезпечує дружнє проростання насіння за наявності вологи. Оптимальним строком сівби для сої є перша половина травня. За таких умов для одержання дружних сходів можна розраховувати на максимальну врожайність. Рання або пізня сівба знижує врожайність насіння сої на 12-14\%.

Ключові слова: соя, строки сівби, фази розвитку, врожсайність.

Постановка проблеми. У зв'язку з інтенсифікацією виробництва сої виникає питання з'ясування елементів технології вирощування, які мають забезпечити високу її продуктивність. Серед них вирішальне значення мають строк, спосіб сівби і норма висіву сої. Необхідність знову повернутися до цього питання обумовлена постійною зміною сортів у виробництві та різними грунтово-кліматичними умовами їх вирощування. Подальше поширення сої в умовах нестійкого зволоження лівобережної частини Лісостепу стримується недостатньо обгрунтованою зональною технологією її вирощування, особливо за ранньої сівби, де тепло $є$ обмежуючим фактором. Потребують вивчення процеси формування врожаю і якості насіння сої за різних строків сівби.

Для сої строк сівби має вирішальне значення, бо від нього залежить дружність сходів, густота рослин, рівномірність достигання, величина i якість врожаю. Основний критерій вибору строку сівби - стійке прогрівання посівного шару грунту. Мінімальна температура для сходів сої становить близько $+10{ }^{\circ} \mathrm{C}$ за тенденції до підвищення температури грунту. Прогрівання посівного шару до $+12-14{ }^{\circ} \mathrm{C}$ забезпечує дружнє проростання насіння за наявності вологи в ньому. За сівби насіння у більш ранній період йому по- трібно більше часу для проростання, що збільшує різке ураження рослин хворобами і шкідниками, знижує схожість насіння [2].

Аналіз основних досліджень і публікацій, у яких започатковано розв'язання проблеми. Строки сівби сої визначаються грунтовокліматичними умовами. За даними Інституту зернового господарства НААН у середньому за 17 років збір насіння сої у разі посіву 18-20 квітня становив 1,27 т/га, 28-30 квітня - 1,58 т/га, 810 травня - 1,65 т/га, 18-20 травня $-1,57$ т/га, 28-30 травня - 1,38 т/га [3]. За сівби сої в оптимальні строки створюються сприятливі умови для швидкого проростання насіння, проходження фаз розвитку, підвищення продуктивності рослин. За порушення строку сівби, глибини загортання насіння або за швидкого пересихання посівного шару грунту, сходи сої недружні, що призводить до різновіковості рослин у посіві. Рослини, сходи яких 3'явилися пізніше, формують меншу листкову поверхню, висоту рослин, слабше гілкуються, на них менше бобів, насіння і бульбочок, що зменшує продуктивність посіву, призводить до нерівномірного дозрівання [1].

Обираючи строки сівби, слід розраховувати на повне використання рослинами вегетаційного періоду, родючості грунту, особливостей вологозабезпечення місцевості, тому що критичний період за водоспоживанням повинен припадати на фазу цвітіння-формування бобів. Дослідження, проведені в зоні Лісостепу України, вказують, що найбільшу урожайність одержано за сівби в роки з ранньою весною наприкінці квітня, в роки з пізньою весною - у першій декаді травня [4].

За сівби в господарствах центрального Лісостепу в ранній строк рекомендують використовувати середньостиглі високопродуктивні сорти coï, а в оптимальні строки - перевагу надавати середньораннім сортам. Перед сівбою обробляти насіння системними протруйниками і стимуляторами росту у поєднанні 3 інокуляцією «Ризоторфіном» та молібденовокислим амонієм [5].

Зміна тривалості періоду сівба - повні сходи 


\section{СІЛЬСЬКЕ ГОСПОДАРСТВО. РОСЛИННИЦТВО}

обумовлена біологічною реакцією сортів сої на строки сівби та складом композицій для обробки насіння. Встановлено, що сівба сої у ранній строк (за температури $6{ }^{\circ} \mathrm{C}$ на глибині 10 см) без обробки насіння системним протруйником призвела до збільшення тривалості періоду сівба повні сходи: для сорту Київська 27 він становив 26 днів і 24 дні для сорту Подільська 1, що відповідно більше на 14 днів порівняно з оптимальним строком за настання температури грунту на глибині 10 см $12{ }^{\circ} \mathrm{C}$. За сівби у ранні строки сої Подільська 1 мала підвищену стійкість до знижених температур у грунті [6].

За оптимального строку сівби спостерігали підвищення схожості насіння сої з 74,2 до 81,4 \% у сорту Київська 27 і з 78,8 до 85,6 \% у сорту Подільська 1. Сівба ж сортів сої у оптимальноранні чи ранні строки призводить до суттєвого зниження польової схожості насіння. Зокрема ці показники у сорту Київська 27 знизились 3 $74,2 \%$ до 56,8-48,5\% і у сорту Подільська 13 $78,8 \%$ до $67,6-52,3 \%$ [2].

Найбільша кількість квіток на одній рослині (74,5-76,5 штук) утворювалася за сівби у третій строк (за температури $14{ }^{\circ} \mathrm{C}$ у грунті на глибині $10 \mathrm{~cm}$ ), проте найсприятливіші умови для утворення зав'язі та формування бобів створювались за сівби в другий строк і застосування заходів захисту від хвороб. Кількість зав'язаних бобів на рослині та бобів, що визріли, становила відповідно 20,1 і 16,1 штук. Ці ж заходи забезпечили i найнижчий рівень абортивності ії генеративних органів (73,4 і 19,9\%) [6].

Низька температура є негативним фактором зовнішнього середовища, що суттєво впливає на ріст і розвиток сої. Властивість культури пристосовуватися до її різкої зміни протягом вегетаційного періоду здебільшого визначає ефективність вирощування. Важливим заходом підвищення стійкості рослин проти тимчасового зниження температури зовнішнього середовища $\epsilon$ передпосівна обробка насіння фізіологічноактивними речовинами, які сприяють стійкості рослин до несприятливих умов зовнішнього середовища. Щоб їх використати, треба правильно оцінити умови вирощування, бо регулятори росту не можуть замінити необхідні фактори життя, а лише допомагають рослині ефективніше їх використати [7].

Метою наших досліджень було вивчення процесів формування врожайності і якості насіння сої за різних строків сівби в умовах Лівобережного Лісостепу України.

У завдання досліджень входило встановлення господарсько-цінних ознак сої за різних строків сівби.

Методика проведення досліджень. Грунт дослідної ділянки - опідзолений чорнозем важкосуглинистого механічного складу. Об'ємна маса грунту коливається по горизонтах від 1,12 до 1,24 г/ $\mathrm{cm}^{3}$. Максимальна гігроскопічність становить $11,6 \%$. Агрохімічні властивості грунту дослідної ділянки (шар грунту 0-30 см) наступні: гумус - 3,4-3,7 \%, pН сольове - 5,8-6,0, гідролітична кислотність - 5,2-5,5 мг/екв., вміст основних поживних речовин: легко гідролізного азоту (за Корнфілдом) - 14,8-16,5, фосфору - 8,8-10,3, калію - 16,7-19,0 мг на 100 грам грунту. Досліди закладали за 4-разового повторення $з$ рендомізованим та стандартним розміщенням ділянок. Схеми дослідів формували, виходячи із завдань дослідження та стану вивчення даного питання. Для цього вивчали декілька типів сортів з різною тривалістю вегетаційного періоду. Спосіб посіву - широкорядний, 3 міжряддями 45 см.

Результати досліджень. Подальше поширення сої в умовах нестійкого зволоження лівобережної частини Лісостепу стримується недостатньо обгрунтованою зональною технологією іiі вирощування, особливо за ранньої сівби, де тепло $\epsilon$ обмежуючим фактором. Потребують вивчення процеси формування врожаю і якості насіння сої за різних строків сівби. Строк сівби для сої має вирішальне значення, так як від нього залежить дружність сходів, густота рослин, рівномірність достигання, величина і якість врожаю. Основний критерій вибору строку сівби - стійке прогрівання посівного шару грунту. Мінімальна температура для сходів сої становить близько $+10{ }^{\circ} \mathrm{C}$ за умови подальшого підвищення температури грунту. Прогрівання посівного шару до $+12-14{ }^{\circ} \mathrm{C}$ забезпечує дружнє проростання насіння за наявності вологи.

У випадку сівби у ранній строк потрібно більше часу для проростання насіння, що збільшує різке ураження рослин хворобами і шкідниками, знижує схожість насіння. Важливим заходом підвищення стійкості рослин проти тимчасового зниження температури зовнішнього середовища $\epsilon$ передпосівна обробка насіння фізіологічноактивними речовинами, які сприяють підвищенню стійкості рослин до несприятливих умов зовнішнього середовища.

Відповідно до мети та завдань дослідження було проведено вивчення впливу строків сівби сої на особливості росту і розвитку рослин у процесі вегетаційного періоду. Фенологічні спостереження за ростом і розвитком сортів сої на ділянках із різними варіантами сівби дали змогу 


\section{СІЛЬСЬКЕ ГОСПОДАРСТВО. РОСЛИННИЦТВО}

встановити деякі відмінності у швидкості проходження фаз розвитку рослин на різних варіантах досліду, що в кінцевому результаті чітко відбилося на датах настання технологічної стиглості рослин сої.

Тривалість міжфазних періодів була різною та залежала, в першу чергу, від погодних умов років досліджень (табл. 1).

Найдовший період вегетації сої відмічено нами в 2015 році. У зв'язку з вищою, порівняно з двома попередніми роками, температурою повітря та нерівномірною кількістю опадів за вегетацію, яка хоча й не перевищувала в сумі ту кількість, яка надійшла у інших звітних роках, однак затяжні дрібні дощі у червні та липні (53,9 та 60,0 мм опадів відповідно) викликали подовження фази цвітіння, інтенсивніше наростання вегетативної маси та збільшення висоти рослин. У цілому вегетаційний період рослин сої подовжився майже на тиждень.

У типовому за погодно-кліматичними умовами та найбільш сприятливому для росту і розвитку рослин сої 2013 році вегетація сої тривала 90103 доби залежно від строку сівби. В найсухішому за роки досліджень 2014 році тривалість вегетації сої була найменшою і варіювала залежно від факторів, поставлених на вивчення - 97100 відповідно.

Особливості формування врожаю у випадку різних строків сівби вплинули на продуктивність сої. Важливим показником, що визначає майбутній урожай є польова схожість насіння. Враховуючи, що насіння мало однакову лабораторну схожість, польова схожість відрізнялась кращими показниками за раннього (64,8 \%) та оптимального (63,9\%) строків сівби.

У разі пізньої сівби польова схожість знизилася до $59,7 \%$, що пояснюємо умовами недостатнього зволоження верхнього шару грунту (табл. 2). Аналіз висоти рослин вказує на їі зменшення за сівби сої у більш пізній строк. За ранньої сівби вона становила 51,1, за пізньої - 44,0 см. Проміжна висота рослин $(47,4$ см) була характерною для оптимального строку сівби з 3 по 11 травня. Висота прикріплення нижніх бобів найвищою була також в оптимальний строк - 14,4 см.

Кількість бобів та насіння на одній рослині також були найбільшими за сівби в оптимальний строк.

Кількість насінин на одній рослині більшою була за пізньої сівби, що пов'язуємо зі зменшенням польової схожості насіння на цих ділянках, a, значить, і густоти рослин.

Знижена маса 1000 насінин була на ділянках ранньої сівби - 123,8, за оптимальної сівби цей показник досягав 134,0, за пізньої сівби - 133,8 г. Урожайність сої за оптимального строку сівби становила 2,11 т/га, за раннього - була нижчою на $11 \%$, за пізнього - на $5 \%$.

\section{1. Проходження фаз розвитку сої сорту залежно від строків сівби та умов вегетаційного періоду}

\begin{tabular}{|c|c|c|c|c|c|c|}
\hline \multirow[b]{2}{*}{ Строк сівби } & \multicolumn{4}{|c|}{ Фаза розвитку } & \multicolumn{2}{|c|}{ Кількість діб } \\
\hline & сходи & цвітіння & $\begin{array}{c}\text { утворення } \\
\text { плодів }\end{array}$ & достигання & $\begin{array}{c}\text { від сівби до } \\
\text { сходів }\end{array}$ & $\begin{array}{c}\text { від сходів до } \\
\text { повної } \\
\text { стиглості }\end{array}$ \\
\hline \multicolumn{7}{|c|}{2013 рік } \\
\hline 28.04 & 11.05 & 3.07 & 1.08 & 22.08 & 14 & 104 \\
\hline 7.05 & 19.05 & 8.07 & 5.08 & 26.08 & 13 & 100 \\
\hline 15.05 & 24.05 & 12.07 & 8.08 & 2.09 & 10 & 102 \\
\hline \multicolumn{7}{|c|}{2014 рік } \\
\hline 30.04 & 14.05 & 5.07 & 3.08 & 21.08 & 15 & 100 \\
\hline 12.05 & 23.05 & 11.07 & 7.08 & 27.08 & 12 & 97 \\
\hline 19.05 & 28.05 & 15.07 & 10.08 & 3.09 & 10 & 99 \\
\hline \multicolumn{7}{|c|}{2015 рік } \\
\hline 26.04 & 8.05 & 2.07 & 29.07 & 19.08 & 13 & 104 \\
\hline 4.05 & 15.05 & 5.07 & 3.08 & 24.08 & 12 & 102 \\
\hline 16.05 & 24.05 & 14.07 & 8.08 & 1.09 & 9 & 100 \\
\hline
\end{tabular}


СІЛЬСЬКЕ ГОСПОДАРСТВО. РОСЛИННИЦТВО

2. Урожайність насіння сої та їі структура залежно від строків сівби (середнє за 2013-2015 рр.)

\begin{tabular}{|c|c|c|c|c|}
\hline \multirow{2}{*}{ № п/п } & \multicolumn{2}{|c|}{ Строк сівби } \\
\cline { 3 - 5 } & Показники & & \\
& & $26-30$ квітня & $4-12$ травня & $15-19$ травня \\
\hline 1 & Лабораторна схожість, \% & 97,6 & 97,6 & 97,6 \\
\hline 2 & Польова схожість, \% & 64,8 & 63,9 & 59,7 \\
\hline 3 & Висота рослин, см & 51,1 & 47,4 & 44,0 \\
\hline 4 & Висота прикріплення нижніх бобів, см & 13,1 & 14,4 & 12,4 \\
\hline 5 & Кількість бобів на 1 рослині & 27,5 & 34,0 & 30,0 \\
\hline 6 & Кількість насіння на 1 рослині & 50,7 & 55,0 & 7,8 \\
\hline 7 & Маса насіння з 1 рослини, г & 6,3 & 7,3 & 133,8 \\
\hline 8 & Маса 1000 насінин, г & 123,8 & 134,0 & 2,01 \\
\hline 9 & Урожайність, т/га & 1,90 & 2,11 & \\
\hline
\end{tabular}

Для сої характерна значна мінливість польової схожості залежно від строку сівби і окремо за роками. Пов'язуємо це з різним температурним режимом у період проростання насіння та умовами зволоження посівного шару грунту, особливо за пізньої сівби. Важливим показником, що характеризує рівень продуктивності сої, є врожайність насіння. Проведені дослідження свідчать, що лише за оптимальних умов для одержання дружних сходів можна розраховувати на максимальну врожайність, яка становила в середньому за три роки досліджень - 1,93 т/га. У разі запізнення з сівбою або за ії раннього проведення зниження врожайності становило в межах 12-14 \%.

\section{Висновки:}

1. Строк сівби для сої має вирішальне значення, так як від нього залежить дружність сходів, гус-

\section{БІБЛІОГРАФІЯ}

1. Алиев Д. А., Акперов 3. И. Фотосинтез и урожай сои / Д. А. Алиев, 3. И. Акперов. - М. : Наука, 1995. - $126 \mathrm{c}$.

2. Бабич А. О. Світові земельні, продовольчі і кормові ресурси / Анатолій Олександрович Бабич. - К. : Аграрна наука, 1996. - 200 с.

3. Бабич А. О. Соя для здоров'я і життя на планеті Земля / Анатолій Олександрович Бабич. К. : Аграрна наука, 1998. - 272 с.

4. Енкен В. Б. Соя : монография / В. Б. Енкен. М. : Сельхозгиз, 1959. -622 с. тота рослин, рівномірність достигання, величина i якість урожаю. Основний критерій вибору строку посіву - стійке прогрівання посівного шару грунту. Мінімальна температура для сходів сої становить близько $+10{ }^{\circ} \mathrm{C}$ за умови подальшого підвищення температури грунту. Прогрівання посівного шару до $+12-14{ }^{\circ} \mathrm{C}$ забезпечує дружнє проростання насіння за наявності вологи.

2. Оптимальним строком сівби для сої є перша половина травня. За таких умов для одержання дружних сходів можна розраховувати на максимальну врожайність, яка становила в середньому за три роки досліджень - 1,93 т/га. У випадку запізнення з сівбою або за іiї раннього проведення зниження врожайності становило в межах 12$14 \%$.

5. Кропивко В. Ф. Вплив мінеральних добрив на розвиток кореневої системи кукурудзи і сої / Віктор Федорович Кропивко // Землеробство. Вип. 3. - 1976. - С. 91-97.

6. Лещенко А. К. Соя / А. К. Лещенко, А. О. Бабич. - К. : Урожай, 1977. - 104 с.

7. Шевніков М. Я. Умови зовнішнього середовища та продуктивність сої і гороху в Лівобережному Лісостепу України / Микола Янаєвич Шевніков // Вісник Полтавської державної аграрної академії. - 2003. - №6. - С. 8-10. 